\title{
ESTIMASI JEJAK KARBON INDUSTRI MINYAK KELAPA SAWIT
}

\section{Carbon Estimation in Palm Oil Industry}

\author{
Mubekti \\ Pusat Teknologi Inventarisasi Sumberdaya Alam - BPPT \\ Gedung Geostech 820, Kawasan Puspiptek, Banten 15314 \\ E-mail: mubekti@gmail.com
}

Diterima: 10 Agustus 2013; Dikoreksi: 23 September 2013; Disetujui: 30 September 2013

\begin{abstract}
In the last decade, Indonesian palm oil production increase rapidly due to both international and domestic demand. The potential use of palm oil as biodiesel to reduce fossil fuel dependency and carbon emissions. The use of fossil fuel is debateable due to carbon emissions to the atmosphere caused by the conversion of land to oil palm estate and subsequent steps in the production. Estimating carbon footprint from palm oil industry can be attributed to three phases of the production process, namely (1) initial conversion of preceding land cover, (2) palm oil cultivation, and (3) transportation and milling processes of palm oil. The secondary data derived from various literature studies indicated that generation of carbon emission estimated up to 1.641,33 tha-1 equivalent $\mathrm{CO}_{2}$ during 25 years of palm oil growing cycle. Since 6000 ha was an economic acreage of palm oil plantation, so estimated of the total carbon emission from this plantation will be $9.847 .980 t$ equivalent $\mathrm{CO}_{2}$. This estimated amount of carbon emission can be used to predict whole population of palm oil plantation in Indonesia.
\end{abstract}

Keywords: Palm oil, carbon emission, carbon sequestration, carbon footprint

\begin{abstract}
Abstrak
Dalam kurun dasawarsa terakhir, produksi minyak kelapa sawit di Indonesia berkembang pesat sebagai akibat dari permintaan baik pasar lokal maupun internasional. Potensi penggunaan minyak sawit sebagai biodiesel untuk mengurangi emisi karbon dan ketergantungan terhadap penggunaan bahan bakar fosil telah menjadi fokus perdebatan berkaitan dengan emisi yang disebabkan oleh konversi lahan perkebunan kelapa sawit, serta proses-proses pengelolaan kebun dan pasca panen. Menghitung jejak karbon dari industri minyak kelapa sawit berkaitan dengan tiga fase proses produksi, yaitu (1) konversi tutupan lahan sebelunya, (2) pengelolaan perkebunan kelapa sawit, (3) transportasi dan pengolahan dalam pabrik. Dari berbagai sumber data sekunder hasil penelitian sebelumnya dapat dihitung emisi karbon sebesar 1.641,33 ton per hektar ekivalen CO2 dalam 25 tahun siklus pertumbuhan kelapa sawit. Apabila 6000 hektar dianggap sebagai luasan ekonomis perkebunan kelapa sawit, maka total emisi karbon diestimasikan sebesar 9.847 .980 ton ekivalen $\mathrm{CO}_{2}$.
\end{abstract}

Kata Kunci: Minyak sawit, emisi karbon, penambatan karbon, jejak karbon

\section{PENDAHULUAN}

Pemanasan suhu bumi diyakini telah terjadi. Sebagai buktinya adalah hasil pengamatan yang menunjukkan kenaikan suhu rata-rata udara dan lautan, mencairnya salju dan es, serta meningkatnya rata-rata tinggi permukaan air laut[1]. Salah satu penyebab utama dari pemanasan global tersebut adalah adanya peningkatan emisi gas rumah kaca (GRK). Sekitar $20 \%$ emisi karbon dioksida $\left(\mathrm{CO}_{2}\right)$ dan gas rumah kaca lain yang menyebabkan perubahan iklim dihasilkan dari perubahan penggunaan lahan di daerah tropis.

Industri kelapa sawit cukup marak dibicarakan, karena dunia saat ini sedang ramai mencari sumber energi baru pengganti minyak bumi yang cadangannya semakin menipis dan juga sebagai sumber emisi karbon yang tinggi. Alternatif pengganti tersebut adalah energi biofuel dimana salah satu bahan baku utamanya adalah minyak mentah kelapa sawit atau yang lebih dikenal dengan nama crude palm oil (CPO). Naiknya permintaan CPO di pasar Internasional menjadi pendorong industri kelapa sawit sebagai andalan 
pertumbuhan ekonomi masa datang. Industri kelapa sawit di Indonesia telah berkembang pesat dengan dukungan pertumbuhan perkebunan yang sangat pesat pula, yaitu mencapai lebih dari 8,0 juta hektar pada tahun 2010; sekitar $62 \%$ diusahakan oleh perkebunan besar dan $38 \%$ oleh perkebunan rakyat[2]. Produksi minyak sawit Indonesia pada tahun 2012 sebesar 27 juta ton, terdiri dari 18 juta ton untuk keperluan ekspor dan sisanya untuk konsumsi domestik.

Bahan bakar biodiesel berbahan dasar minyak kelapa sawit kerapkali menjadi fokus perdebatan yang terkait dengan emisi yang disebabkan oleh konversi lahan untuk perkebunan kelapa sawit. Penjualan CPO Indonesia ke Eropa terganjal isu lingkungan, terutama mengenai carbon footprint (jejak karbon). Uni Eropa mensyaratkan sawit yang dijadikan bahan bakar nabati harus mengurangi emisi karbon sebesar $35 \%$ dibandingkan dengan bahan bakar fosil. Untuk berargumentasi secara ilmiah dan masuk logika terhadap regulasi yang dibuat oleh Eropa secara sepihak, Indonesia harus melakukan langkah strategis melalui penelitian kuantitatif jejak karbon yang berkelanjutan untuk mendapatkan basis analisis serta sebagai bahan pertimbangan untuk negosiasi dengan Uni Eropa.

Secara umum jejak karbon (carbon footprint) didefinisikan sebagai jumlah gas rumah kaca (GRK) yang teremisikan sebagai akibat dari kegiatan manusia baik secara langsung maupun tidak langsung. GRK yang teremisi terdiri dari beberapa jenis, namun pada umumnya adalah karbon dioksida $\left(\mathrm{CO}_{2}\right)$ dan metana $\left(\mathrm{CH}_{4}\right)$ dan diekspresikan dalam satuan berat ekivalen karbon -dioksida, misalnya ton ekivalen $\mathrm{CO}_{2}$. Sesuatu hal yang sulit untuk menghitung jejak karbon secara total karena membutuhkan data yang banyak dan besar. Berkaitan dengan hal tersebut, penghitungan jejak karbon dibatasi pada populasi tertentu dengan mempertimbangkan cadangan, sumber, dan perosot (storage, source, dan sink) yang utama dalam ruang dan tempo tertentu pula [3].

Penelusuran jejak karbon dalam proses produksi CPO (Crude Palm Oil) difokuskan pada 3 fase pokok [4], yaitu: Konversi lahan dalam proses 'land clearing' menjadi perkebunan kelapa sawit akan terjadi emisi net-C (C debt)Pengelolaan perkebunan, dimana dalam proses ini terjadi emisi dan absorbdi karbon. Transport dari kebun ke pabrik, proses di pabrik dan transport ke 'end user'

Besaran emisi karbon pada proses konversi lahan tergantung dari tutupan lahan dan jenis tanah sebelumnya. Tutupan lahan yang berbeda, seperti hutan primer, hutan sekunder, bekas lahan perkebunan, lahan terlantar (alang-alang), semak belukar dan lain-lain, mempunai cadangan karbon tersimpan yang berbeda pula. Sedangkan jenis tanah dibedakan menjadi dua, yaitu tanah mineral (mineral soil) dan tanah gambut (peat soil). Tanah gambut yang terbentuk dari sisa-sisa bahan organik mempunyai cadangan karbon jauh lebih besar daripada tanah mineral. Dalam bahasan ini diasumsikan jenis tutupan lahan sebelumnya adalah hutan lahan basah, sedangkan jenis tanah diasumsikan tanah gambut.

Neraca emisi dan absorbsi karbon tergantung tingkat pengelolaan perkebunan. Perlakuan pemupukan yang baik akan menyuburkan tanaman, sehingga akan banyak menyerap (penambatan) karbon dioksida $\left(\mathrm{CO}_{2}\right)$ dari udara dalam proses fotosintesis dan disimpan dalam bentuk biomasa tanaman. Sedangkan jenis pupuk yang mengandung unsure nitrogen akan mengemisikan GRK, yaitu dalam bentuk metan $\left(\mathrm{NH}_{4}\right)$. Pengelolaan sisa-sisa bahan organic dari perkebunan juga akan mempengaruhi besaran emisi karbon.

Bahan bakar untuk transportasi baik antar perkebunan, maupun dari perkebunan ke pabrik CPO akan menghasilkan emisi karbon. Demikian juga dengan pengelolaan limbah pabrik, baik padatan maupun cairan akan menghasilkan emisi karbon. Tulisan ini akan menghitung secara kuantitatif jejak karbon yang dihasilkan oleh produksi minyak kelapa sawit di Indonesia.

\section{BAHAN DAN METODE}

\subsection{Perhitungan Jejak Karbon}

Dalam tulisan ini diasumsikan, bahwa perkebunan kelapa sawit berasal dari konversi hutan rawa gambut. Perhitungan jejak karbon didasarkan pada penjumlahan emisi dari masing -masing proses/kegiatan dalam fase produksi minyak sawit, kemudian emisi pada seluruh fase produksi dikomulatifkan.

Fase konversi lahan menghasilkan emisi karbon terutama dari adanya kebakaran biomassa tanaman dan kebakaran lapisan tanah gambut. Kemudian dalam fase pengelolaan perkebunan ada 4 proses yang secara signifikan menghasilkan emisi dan sekuestrasi, yaitu dekomposisi gambut, aplikasi pupuk dan pestisida, bahan bakar transportasi dan mesin pertanian, dan sekuestrasi (penyerapan) karbon oleh tanaman. Fase pemrosesan pasca panen menghasilkan emisi karbon terutama bersumber dari limbah padat dan limbah cair.

Emisi alat transportasi dari pabrik ke pengguna akhir (end user) tidak dibahas dalam tulisan ini karena kesulitan mendapatkan sumber informasi.

\subsection{Cara Perhitungan}

Pengumpulan data sekunder diperoleh dari berbagai sumber terutama dari hasi-hasil penelitian yang dilakukan baik di Indonesia maupun di luar 
negeri. Variasi data hasil-hasil penelitian sangat beragam baik dari satu peneliti ke peneliti lainnya maupun dari lokasi penelitiannya. Perhitungan emisi karbon dalam tulisan ini didasarkan pada nilai tengah dari berbagai sumber data yang diperoleh. Secara ekonomis siklus pertumbuhan kelapa sawit adalah 25 tahun, oleh karena itu perhitungan emisi karbon juga didasarkan pada kurun siklus pertumbuhan ekonomis tersebut. Satuan emisi karbon dalam tulisan ini adalah ekivalensi dengan karbon dioksida $\left(\mathrm{CO}_{2}\right)$, oleh karena itu emisi gas rumah kaca yang lain juga dikonversikan dalam bentuk ekivalen $\mathrm{CO}_{2}$.

\section{HASIL DAN PEMBAHASAN}

\subsection{Emisi Karbon pada Konversi Lahan}

Perubahan pengunaan lahan dari vegetasi menjadi nonvegetasi dapat merubah albedo dan jumlah sinar matahari yang dapat diserap oleh permukaan tanaman, selain itu juga menjadi salah satu penyebab perubahan iklim secara global [5]. Karbon tersimpan di setiap penggunaan lahan selalu berbeda, bahkan untuk satu tutupan lahan sekalipun. Keadaan ini dipengaruhi oleh beberapa faktor seperti struktur vegetasi, pengelolaan yang berbeda dan rezim iklim [6]. Faktor iklim seperti curah hujan, suhu, dan kelembaban memiliki pengaruh besar terhadap pertumbuhan pohon, dan tentunya berpengaruh langsung terhadap besar kecilnya stok karbon. Dalam [7] menjelaskan bahwa kadar kandungan karbon tersimpan di dalam biomassa pada hutan tropis berkisar antara $41.5 \%$ sampai $50 \%$. Selanjutnya menurut[8] bahwa hutan-hutan di Indonesia diperkirakan memiliki stok karbon tersimpan antara 161 ton ha-1 sampai 300 ton ha-1.

Pembukaan lahan untuk perkebunan kebanyakan dilakukan dengan cara menebang dan membakar pepohonan atau alang-alang (sistem tebang-bakar). Pembakaran vegetasi mengakibatkan hampir semua cadangan $\mathrm{C}$ dan $\mathrm{N}$ hilang, tetapi para pelaku seperti pengusaha masih tetap memilih cara ini karena mudah dan murah.

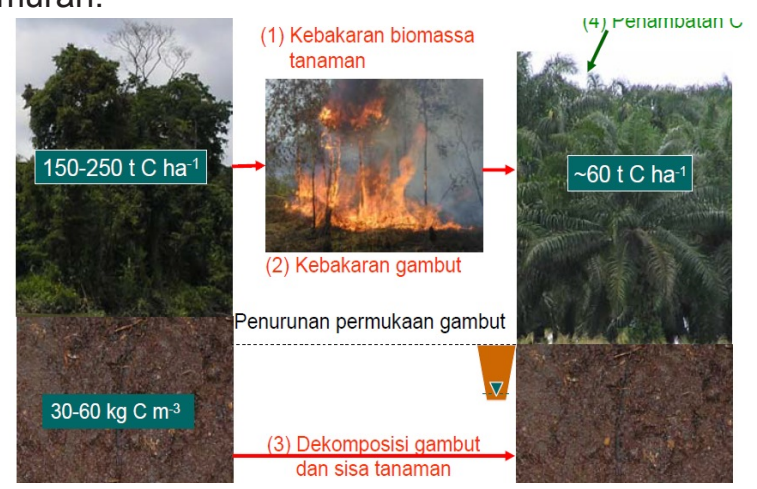

Gambar 1. Ilustrasi emisi dan penambatan karbon pada komversi hutan rawa gambut [9]
Gambar 1 mengilustrasikan emisi dan penambatan karbon pada konversi lahan hutan gambut untuk perkebunan kelapa sawit melalui proses pembakaran. Mengindikasikan terjadi emisi netto pada saat proses pembukaan lahan yang bersumber dari biomasa permukaan dan lapisan gambut yang terbakar. Sedangkan pada proses budidaya perkebunan terjadi emisi karbon yang berasal dari dekomposisi gambut akibat pembangunan drainase dan penambatan karbon oleh tanaman perkebunan. Sesuai dengan perkembangan jumlah biomasa tanaman yang dibudidayakan, terdapat akumulasi penambatan (sekuestrasi) karbon selama satu siklus pertumbuhan. Tanaman perkebunan sawit misalnya mempunyai siklus pertumbuhan sekitar 25 tahun untuk mencapai produksi yang optimum. Rata-rata sekuestrasi karbon pada tanaman kelapa sawit sebesar 60 ton ha-1.

Emisi karbon bersih (C-debt) pada fase pembukaan lahan merupakan penjumlahan emisi karbon karena terbakarnya biomasa permukaan lahan dan kebakaran lapisan gambut bagian atas.

\section{Emisi kebakaran biomassa tanaman}

Menurut [10] biomassa tanaman pada hutan lahan basah/gambut menyimpan sekitar 200 t C ha ${ }^{-1}$. Karbon yang tersimpan tersebut akan hilang dengan cepat apabila hutan ditebang. Penebangan yang diikuti dengan pembakaran mempercepat proses emisi dari biomassa hutan gambut. Sekitar $50 \%$ dari kayu penebangan hutan dipanen untuk dijadikan berbagai bahan perabotan dan perumahan

Karbon di dalamnya akan tersimpan dalam waktu cukup lama (10-25 tahun) sehingga bisa dianggap menjadi bagian dari karbon tersimpan satu sampai tiga dekade sesudah hutan dibuka, tergantung kualitas kayunya. Sisa pohon yang tertinggal di atas permukaan tanah akan teremisi dalam waktu yang relatif singkat, baik karena terbakarnya biomassa kayu-kayuan tersebut, maupun karena pelapukan secara biologis. Dari 100 t C ha-1 biomassa tanaman yang tidak digunakan sebagai produk kayu hasil hutan, akan menjelma menjadi sekitar 367 t CO2 ha-1 bila teroksidasi secara sempurna. Dalam satu siklus pertumbuhan kelapa sawit, hanya terjadi satu kali konversi hutan. Penghitungan emisi karbon dari biomasa yang terbakar seperti berikut:

Emisi = C tanaman yang terbakar * 3,67

Angka 3,67 adalah factor konversi dari C ke CO2. Berat atom $\mathrm{C}=12$, berat atom $\mathrm{O}=16$

Kandungan $\mathrm{C}$ hutan gambut 100 t.ha-1, maka Emisi $=100$ t C ha- ${ }^{*} 3,67 \mathrm{CO} 2 / \mathrm{C}=367$ t CO2 ha-1 


\section{Emisi Kebakaran lapisan gambut}

Apabila biomassa tanaman hutan gambut terbakar maka tidak hanya biomassa tanaman saja yang akan terbakar, tetapi juga beberapa centimeter lapisan gambut bagian atas yang berada dalam keadaan kering. Lapisan gambut ini akan rentan kebakaran apabila muka air tanah lebih dalam dari $30 \mathrm{~cm}$. Pada tahun El Nino seperti tahun 1997, muka air tanah menjadi lebih dalam karena penguapan sehingga lapisan atas gambut menjadi sangat kering. Dalam keadaan demikian kebakaran gambut dapat mencapai ketebalan $50 \mathrm{~cm}[11]$. Dalam keadaan ekstrim ini bara api pada tanah gambut dapat bertahan berminggu -minggu. Untuk tahun normal[12] memperkirakan kedalaman gambut yang terbakar sewaktu pembukaan hutan sedalam $15 \mathrm{~cm}$. Apabila kandungan karbon gambut rata-rata adalah 40 $\mathrm{kg} \mathrm{m}-3$, maka dengan terbakarnya $15 \mathrm{~cm}$ lapisan gambut akan teremisi sebanyak 75 t $\mathrm{C}$ ha-1 atau ekivalen dengan 275 t CO2 ha $^{-1}$.

Kandungan karbon dalam bahan organik gambut tergantung dari karakteristik gambut itu sendiri. Kerapatan lindak atau bobot isi (bulk density: BD) gambut umumnya berkisar antara 0,05 sampai $0,40 \mathrm{gram} / \mathrm{cm} 3$. Nilai kerapatan lindak ini sangat ditentukan oleh tingkat pelapukan/ dekomposisi bahan organik, dan kandungan mineralnya[13]. Secara umum BD gambut akan meningkat apabila tingkat dekomposisinya sudah lanjut, dan sebaliknya persentasi karbon organiknya akan menurun. Tabel 1 berikut mengindikasikan BD dan persentasi C-organik dari berbagai tingkat dekomposisi gambut [14]. Kalau diasumsikan lapisan gambut yang terbakar mempunyai tingkat kematangan fibrik maka perhitungan emisina seperti ang terlihat dalam Kotak Teks berikut:

\subsection{Emisi Karbon pada Pengelolaan Perkebunan}

Dalam pengelolaan perkebunan terjadi emisi dan sekuestrasi karbon. Emisi bersumber dari dekomposisi gambut, aplikasi pupuk dan pestisida, dan bahan bakar transportasi dan mesin pertanian. Sedangkan sekuestrasi karbon terjadi pada proses fotosintesis, dimana karbon diserap oleh tanaman dan disimpan sebagai biomasa.

\section{Emisi dari Dekomposisi Gambut}

Proses emisi pada lahan gambut tidak berhenti sesudah pembukaan hutan. Selama masa budidaya tanaman pertanian, emisi dalam jumlah tinggi tetap terjadi disebabkan dekomposisi gambut oleh mikroorganisme. Tingkat dekomposisi gambut sangat dipengaruhi oleh kedalaman drainase, dimana semakin dalam drainase, semakin cepat terjadinya dekomposisi gambut. Faktor-faktor lain seperti kadar air tanah, pemupukan, dan suhu tanah, sangat mempengaruhi jumlah emisi selain kedalaman muka air tanah gambut.

Hasil review sejumlah literatur yang dilakukan oleh [15], mengemukakan bahwa untuk kedalaman drainase antara 30 sampai $120 \mathrm{~cm}$, emisi akan meningkat sebesar 0,91 $\mathrm{t} \mathrm{CO}_{2} \mathrm{ha}^{-1}$ tahun $^{-1}$ untuk setiap penambahan kedalaman drainase sedalam $1 \mathrm{~cm}$. Apabila untuk kelapa sawit drainase rata-ratanya diasumsikan sedalam $60 \mathrm{~cm}$, dengan menggunakan hubungan tersebut maka emisi tahunan adalah sekitar $54,6 \mathrm{t} \mathrm{CO}_{2}$ ha1.

Akan tetapi nilai emisi sangat bervariasi antar berbagai penelitian. Misalnya, penelitian[16] pada perkebunan kelapa sawit dengan kedalaman drainase $80 \mathrm{~cm}$ menemukan tingkat emisi setinggi 54 t CO2 ha-1 tahun-1, namun[17] dari pengukuran emisi di hutan gambut sekunder menemukan emisi setinggi 127 t CO2 ha-1 tahun-1.

Menurut [18] subsiden berlangsung sangat cepat beberapa tahun pertama sesudah gambut didrainase dan kemudian akan mencapai kestabilan sekitar $2 \mathrm{~cm} / \mathrm{th}$. Total subsiden dalam 25 tahun siklus pertumbuhan ekonomi kelapa sawit sebesar $100 \mathrm{~cm}$. Dijelaskan lebih jauh bahwa dengan asumsi tidak terjadi kebakaran, maka dekomposisi gambut menyumbang 60 $\%$ terhadap subsiden sedangkan pemadatan (konsolidasi) menyumbang $40 \%$. Berdasarkan pada [18], emisi karbon dari dekomposisi gambut dapat dihitung sebagai beriku:

Dekomposisi $(25 \mathrm{th})=60 \% * 100 \mathrm{~cm}=0,60 \mathrm{~m}$

Kerapatan karbon: $\mathrm{Cd}=0,05 \mathrm{t} / \mathrm{m3}$

Angka konversi $\mathrm{C}$ ke $\mathrm{CO} 2=3,67 \mathrm{CO} 2 / \mathrm{C}$

Dekomposisi $=0,60 * 0,05 * 3,67 * 10.000$

$$
=1101 \mathrm{t} \mathrm{CO} 2 / \mathrm{ha} / 25 \mathrm{th}
$$

\section{Emisi Aplikasi Pupuk dan Pestisida}

Kemampuan lahan dalam penyediaan unsur hara secara terus-menerus bagi pertumbuhan dan perkembangan tanaman kelapa sawit sangatlah terbatas. Keterbatasan daya dukung lahan dalam penyediaan hara ini harus diimbangi dengan penambahan unsur hara melalui pemupukan.

$$
\begin{aligned}
& \text { Emisi }=\text { vol. gambut }(\mathrm{m} 3){ }^{*} \mathrm{Cd} * 3,67 \mathrm{CO} 2 / \mathrm{C} \\
& \text { Cd kandungan karbon (t C/m3) } \\
& \mathrm{Cd}=\mathrm{Db}{ }^{*} \mathrm{C} \\
& \mathrm{Db}=\text { bulk density }(0.1028 \text { (gr/cc) } \\
& \mathrm{C}=\% \text { C organik }(53.31 \%) \\
& \text { Emisi }=(0,15 * 10.000) * 0,05 * 3,67 \\
& =275,25 \mathrm{t} \mathrm{CO} 2 / \mathrm{ha}
\end{aligned}
$$

Dosis pemupukan sangat bervariasi tergantung dari tingkat intensitas pengelolaannya. Perkebunan inti, plasma dan tradisional 
mempunyai perbedaan dosis yang besar dikarenakan kemampauan investasi pemupukan juga jauh berbeda.
Tabel 2, merupakan referensi jumlah input pupuk rata-rata untuk perkebunan kelapa sawit.

Tabel 1. BD dan kadar C-Organik pada tiap jenis/ tingkat kematangan gambut

\begin{tabular}{llllll}
\hline No. & \multicolumn{1}{c}{ Tingkat } & \multicolumn{2}{c}{ Bobot Isi-BD (gr/cc) } & \multicolumn{2}{c}{ C-Organik (\%) } \\
& \multicolumn{1}{c}{ Kematangan Gambut } & Kisaran & Rerata & Kisaran & Rerata \\
\hline 1. & Fibrik & $0.1012-0.12$ & 0.1028 & - & 53.31 \\
2. & Hemik & $0.1325-0.29$ & 0.1716 & $38.97-51.87$ & 48.00 \\
3. & Saprik & $0.2492-0.37$ & 0.2794 & $28.96-53.89$ & 44.95 \\
4. & Peaty/sangat dangkal & $0.2152-0.6878$ & 0.3402 & $28.96-39.81$ & 35.12 \\
\hline
\end{tabular}

Tabel 2. Jumlah input pupuk untuk perkebunan kelapa sawit dari berbagai sumber

\begin{tabular}{|c|c|c|c|c|}
\hline Input & (19) & $(20)$ & 1) & (22) \\
\hline $\begin{array}{c}\text { Ammonium nitrate } \\
\left(\mathrm{kg} \mathrm{N} \mathrm{ha} \mathrm{hh}^{-1}\right) \\
\text { Ammonium }\end{array}$ & 100 & - & $\begin{array}{l}96- \\
100\end{array}$ & 93 \\
\hline $\begin{array}{c}\text { sulphate }(\mathrm{kg} N \text { ha } \\
\left.\mathrm{th}^{-1}\right)\end{array}$ & - & 88.2 & - & - \\
\hline $\begin{array}{l}\text { Phosphate rock } \\
\left(\mathrm{kg} \mathrm{P} \mathrm{P}_{5} \mathrm{ha}^{-1} \mathrm{th}^{-1}\right)\end{array}$ & 45 & 34.6 & $28-45$ & 114 \\
\hline $\begin{array}{c}\text { chloride }(\mathrm{kg} \mathrm{K} 20 \\
\left.\mathrm{ha}^{-1} \mathrm{th}^{-1}\right)\end{array}$ & 205 & 252.0 & $\begin{array}{l}172- \\
205\end{array}$ & 200 \\
\hline $\begin{array}{c}\text { Kieserite ( } \mathrm{kg} \text { MgO } \\
\left.\mathrm{ha}^{-1} \mathrm{th}^{-11}\right)\end{array}$ & 50 & 39.2 & $33-48$ & 27 \\
\hline
\end{tabular}

Pupuk organik yang diaplikasikan secara teratur pada perkebunan kelapa sawit merupakan pupuk/limbah dari proses pengolahan kelapa sawit dan limbah perkebunan yang berasal dari sisa-sisa daun kacang-kacangan yang sengaja ditanam pada saat pembukaan lahan. Pengaruh bahan organik terhadap pertumbuhan tanaman terutama karena kemampuannya memperbaiki sifat fisik dan kimia tanah. Pemupukan kelapa sawit dilakukan pada 3 tahap, yaitu tahap pembibitan, dan TBM (Tanaman Belum Menghasilkan) mengacu pada dosis baku, serta tahap TM (Tanaman Menghasilkan) mengacu pada perhitungan faktor-faktor dasar serta konsep neraca hara (nutrient balance). Neraca hara, didasarkan pada dosis pupuk yang diberikan diperhitungkan dengan kebutuhan hara tanaman dan hara yang disediakan oleh tanah.

Pestisida adalah bahan-bahan yang dapat membunuh organism pengganggu tanaman (hama, penyakit, dan gulma). Bahan-bahan ini dapat berupa zat kimia, mikroorganisme, maupun bahan tanaman lainnya. Berdasarkan sasarannya pestisida terdiri dari: fungisida, herbisida, insektisida, rodentisida, dan akarisida.

Emisi GRK yang berkaitan dengan penggunaan pupuk dan pestisida dalam perkebunan kelapa sawit terdiri dari dua elemen[22], yaitu: Emisi yang terjadi selama proses produksi dan transport, bervariasi tergantung dari jenis. Emisi N2O yang terjadi selama aplikasi pupuk nitrogen.

Menurut pedoman [23], bahwa $1 \%$ N2O-N dari total pupuk $\mathrm{N}$ yang diberikan akan teremisi, dan emisi dari gas ini mempunyai potensi 296 kali lebih besar terhadap pemanasan global daripada emisi CO2. Berdasarkan estimasi[21], bahwa secara keseluruhan emisi GRK dari pupuk dan pestisida untuk perkebunan kelapa sawit berkisar 1.0861.500 kg ekivalen CO2/ha/tahun. Sedangkan[24] mengestimasikan bahwa total emisi GRK yang berhubungan dengan penggunaan pupuk kimia (buatan) sebesar 1.409 kg ekivalen CO2 ha-1th-1. Demikian juga nilai patokan yang dipakai oleh[25] berkisar antara 1.000-1.500 kg ekivalen CO2/ha/ tahun.

Berdasarkan kajian dari berbagai literatur yang dilakukan oleh[25], mengajukan kepada RSPO, bahwa emisi GRK yang berasal dari penggunaan pupuk buatan dan pestisida berkisar antara 1.000$1.500 \mathrm{~kg}$ ekivalen CO2/ha/tahun dengan nilai tengah $1.2501 .250 \mathrm{~kg} \mathrm{CO} 2 / \mathrm{ha} / \mathrm{th}$. Kotak Teks berikut adalah estimasi emisi karbon dari aplikasi pupuk dan pestisida

Nilai tengah emisi $=1.250 \mathrm{~kg} \mathrm{CO} 2 / \mathrm{ha} / \mathrm{th}$ $=1,25$ ton $\mathrm{CO} 2 / \mathrm{ha} / \mathrm{th}$ 
Nilai emisi 25 tahun $=25 * 1,25$ ton $\mathrm{CO} 2 /$ ha/th

$$
=31,25 \text { t CO2/ha }
$$

\section{Emisi Transpotasi Kebun dan Mesin Pertanian}

Pada umumnya bahan bakar yang digunakan internal perkebunan berupa bahan bakar fosil, terutama minyak solar. Bahan bakar solar digunakan untuk mesin pertanian, perawatan, pemanenan, koleksi hasil panen, dan transport internal antar kebun sawit dan ke pabrik.

Estimasi [21] menunjukkan, bahwa konsumsi solar sebesar 58-70 liter ha-1th-1 pada perkebunan kelapa sawit, dan ekivalensi emisi CO2 sebesar 3,1 $\mathrm{kg} /$ liter solar setara dengan 180-217 kg ekivalen CO2 ha-1th-1. Konsumsi energy yang digunakan untuk kendaraan dan mesin pertanian diestimasi oleh[27] sebesar 4.7 GJ ha-1th-1. Setiap $1 \mathrm{MJ}$ solar diasumsikan mempunyai emisi 0,086 kg ekivalen $\mathrm{CO} 2$, sehingga emisi tahunan dari transport dan permesinan menghasilkan angka $404 \mathrm{~kg}$ ekivalen CO2 ha-1th-1. Sedangkan[22] menghitung konsumsi solar pada tingkat perkebunan sebesar 33 liter ha-1th-1, transport dari perkebunan ke pabrik sebesar 1,5 liter/ton TBS, dan pabrik minyak sawit membutuhkan 0,45 leter/ton TBS. Studi mereka kemudian mengasumsikan, bahwa rata -rata produktivitas TBS sebesar 19 ton ha-1th-1, sehingga secara keseluruhan konsumsi solar setara dengan 70 liter/ha/tahun. Dengan asumsi emisi karbon sebesar 3,208 kg ekivalen CO2/ton solar, maka akan menghasilkan kesetaraan emisi 225 kg ekivalen CO2 ha-1th-1.

Berdasarkan hasil-hasil dari berbagai sumber tersebut diatas diasumsikan, bahwa emisi karbon yang bersumber dari bahan bakar transportasi internal perkebunan dan mesin-mesin pertanian bervariasi sekitar 180-404 kg ekivalen CO2 ha -1th-1, dengan nilai tengah $290 \mathrm{~kg}$ ekivalen CO2 ha-1th-1.

Nilai tengah emisi $=290 \mathrm{~kg} \mathrm{CO} 2$ ha- 1 th- 1

$$
=0,29 \mathrm{t} \mathrm{CO} 2 \text { ha- } 1 \text { th }-1
$$

Nilai emisi 25 tahun $=25 * 0,29$ t CO2 ha- 1 th -1

$$
=7,25 \text { t CO2 ha- } 1
$$

\section{Sekuestrasi Karbon oleh Tanaman}

Tanaman kelapa sawit menyerap gas asam arang (CO2) dari udara melalui proses fotosintesis, yang selanjutnya diubah menjadi karbohidrat, kemudian disebarkan ke seluruh tubuh tanaman dan akhirnya ditimbun dalam tubuh tanaman. Proses penimbunan karbon (C) dalam tubuh tanaman hidup dinamakan proses sekuestrasi (C-sequestration). Dengan demikian mengukur jumlah yang disimpan dalam tubuh tanaman hidup (biomasa) pada suatu lahan dapat menggambarkan banyaknya $\mathrm{CO} 2$ di atmosfer yang diserap oleh tanaman. Sedangkan pengukuran cadangan yang masih tersimpan dalam bagian tumbuhan yang telah mati (nekromasa) secara tidak langsung menggambarkan $\mathrm{CO} 2$ yang tidak dilepaskan ke udara lewat pembakaran[ 5].

Selama masa pertumbuhan tanaman akan terjadi sekuetrasi (penambatan) karbon yang jumlahnya sangat ditentukan oleh jumlah biomassa tanaman. Karbon tersimpan sangat ditentukan oleh umur tanaman, oleh karena itu dalam penentuannya digunakan nilai time average (rerata simpanan karbon dalam satu siklus hidup tanaman). Kelapa sawit mampu menyimpan lebih dari 80 ton $C$ ha-1. Akan tetapi dikatakan oleh[28], bahwa jumlah tersebut dicapai setelah 10-15 tahun pertumbuhan sehingga jumlah karbon rata -rata waktu yang ditambat oleh tanaman kelapa sawit sekitar 60,4 t ha-1 atau rata-rata sekitar 2,44 t C ha-1 tahun-1 dan ekivalen dengan 8,95 t CO2 ha-1 tahun-1. Gambar 2, mengilustrasikan proses penyimpanan karbon dalam satu siklus pertumbuhan kelapa sawit.

Gambar 2. Karbon tersimpan dalam tanaman kelapa sawit di berbagai umur serta nilai time average $C$ [28].

Hasil hitungan sekuestrasi karbon selama satu siklus pertumbuhan kelapa sawit.

Sekuestrasi $=$ Rerata waktu simpan C * 3,67

Rerata waktu simpan $\mathrm{C}$ satu siklus $=60,4 \mathrm{t} \mathrm{C}$ ha- 1

Sekuestrasi 25 tahun $=60,4$ t C/ha ${ }^{*} 3,67$

$=221,67$ t CO 2 ha- 1

\subsection{Emisi Karbon Pasca Panen}

Penggilingan Kelapa sawit intinya adalah pengolahan Tandan Buah Segar (TBS) menjadi CPO (crude Palm Oil) dan PKO (Palm Kernel Oil). Dalam proses penggilingan tersebut akan mempunyai hasil sampingan, yaitu berupa limbah padat, terdiri dari tandan buah kosong (TBK), serat, cangkang, abu ketel, dan limbah cair (POME). Limbah-limbah tersebut akan mengemisikan karbon apabila tidak dikelola dengan baik.

\section{Emisi Limbah Padat}

Dalam proses pengolahan minyak sawit diperlukan uap panas yang dihasilkan oleh ketel uap. Ketel uap pada umumnya membutuhkan bahan bakar dari hasil sampingan (residu), seperti serat dan cangkang biji kelapa sawit. Penggunaan bahan bakar dari serat dan cangkang tersebut akan menghasilkan emisi GRK, terutama CO2 sedangkan GRK yang lain diabaikan.

Residu padat lain dari pabrik minyak sawit adalah tandan buah kosong (TBK). TBK dapat dimanfaatkan sebagai mulsa di perkebunan, 
diolah menjadi pupuk kompos, atau sebagai biofuel, dan masing-masing pemanfaatan TBK tersebut menghasilkan emisi GRK dengan karakter yang spesifik. Pada saat ini, pada umumnya pemanfaatan TBK adalah untuk mulsa diperkebunan. Pemanfaatan untuk mulsa mempunyai potensi untuk mengurangi emisi GRK berkaitan dengan pengurangan penggunaan pupuk buatan, dan meningkatkan penambatan karbon dan kandungan bahan organik dalam tanah. Walaupun demikian belum ada data kuantitatif mengenai besaran pengurangan emisi GRK, sehingga pemanfaatan TBK untuk mulsa dianggap tidak berpengaruh terhadap emisi karbon[22]. Pemanfaatan TBK untuk kompos atau dipendam dalam tanah akan menghasilkan emisi methan sebagai akibat dari proses dekomposisi anaerobik[29].

Pemanfaatan hasil sampingan pabrik minyak sawit dan residu lainnya (serat dan cangkang) sangat mengurangi secara signifikan pengguaan bahan bakar fosil. Berdasarkan telaah pustaka, bahwa dipertimbangkan tidak ada emisi netto GRK yang timbul akibat penggunaan bahan bakar pabrik minyak sawit dan penggunaan hasil sampingan dan residu lainnya.

\section{Emisi pada Limbah Cair}

Selama proses penggilingan Tandan Buah Segar (TBS) akan dihasilkan limbah cair yang biasa disebut sebagai 'Palm Oil Mill Effluent (POME)'. POME selain mempunyai volume yang paling besar diantara limbah yang lain juga paling membahayakan lingkungan[30]. Pada umumnya perlakukan terhadap POME dilakukan dengan sistem kolam. Secara alamiah oksigen yang tersedia di sistem kolam perlakuan tidak mampu memenuhi kebutuhan dekomposisi aerobik bahan organik yang terkandung dalam limbah cair, sehingga proses dekomposisi berjalan secara anaerobik dan akan menhhasilkan biogas yang dilepas ke atmosfer. Sebagian besar biogas yang dihasilkan dari dekomposisi POME adalah methan (CH4) yang merupakan sumber emisi GRK.

Temuan [31] menunjukkan, bahwa kandungan rata-rata methan dalam POME sebesar $54 \%$. Sedangkan[24] mengkalkulasi, bahwa methan dari POME yang dilepas setara dengan $9 \mathrm{~kg} / \mathrm{ton}$ TBS (diasumsikan 0,7 m3 POME/ton TBS, $28 \mathrm{~m} 3$ biogas/m3 POME dan $65 \% \mathrm{CH} 4$ dalam biogas). Dari hasil-hasil studi tersebut diperkirakan terdapat emisi GRK tambahan sebesar $190 \mathrm{~kg}$ ekivalen CO2 per ton TBS. Selanjutnya[21] menggunakan emisi dari POME berkisar antara 2.500 - 3.800 $\mathrm{kg}$ ekivalen CO2/ha/tahun. Berdasarkan telaah literatur yang dilakukan oleh Klaarenbeeksingel (2009), emisi GRK dari POME berkisar antara $2.500-4.000 \mathrm{~kg}$ ekivalen CO2/ha/tahun dengan nilai tengah $3.250 \mathrm{~kg}$ ekivalen CO2/ha/tahun. Jadi emisi karbon dari limbah cair seperti berikut:

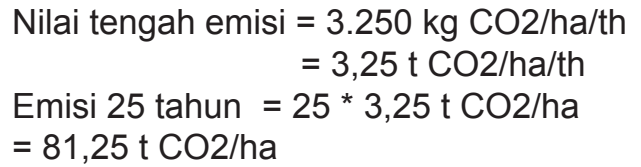

\section{KESIMPULAN}

Berdasarkan hasil telaah literature tersebut diatas, penghitungan jejak karbon industri minyak sawit mulai dari konversi lahan hutan gambut sampai dengan pabrik CPO dan PKO merupakan penjumlahan emisi dan sekuestrasi karbon sebagai berikut: (1) Emisi dari pembakaran biomasa dalam proses 'land clearing'; (2) Emisi dari terbakarnya lapisan atas lahan gambut; (3) Emisi dari dekomposisi lahan gambut; (4) Emisi dari aplikasi pupuk; (5) Emisi dari Aplikasi pupuk dan pestisida; (6) Sekuestrasi oleh tanaman sawit; (7) Emisi dari limbah cair

Dari ketujuh sumber emisi dan sekuestrasi tersebut menghasilkan neraca emisi karbon sebesar 1.641,33 ton ha-1 ekivalen CO2 dalam kurun 25 tahun (satu siklus pertumbuhan kelapa sawit). Kalau lahan yang diperhitungkan adalah 6.000 ha, yaitu luasan sekala ekonomis perkebunan kelapa sawit, maka total emisi karbon sebesar 9.847.980 ton ekivalen CO2. Angka tersebut tentunya akan jauh lebih kecil apabila konversi lahan dilakukan pada lahan mineral yang terlantar, seperti semak belukar, dan alang-alang.

\section{DAFTAR PUSTAKA}

1. IPCC, (2007). Climate Change 2007. Synthesis Report. A Report of the Intergovernmental Panel on Climate Change. WMO - UNEP.

2. Ditjenbun-Kementan, (2012). Kebijakan Pengembangan Komoditas Perkebunan Strategis. Raker Akselerasi Industrialisasi dalam Rangka Mendukung Percepatan dan Pembangunan Ekonomi. Jakarta, 1 Pebruari 2012

3. Wright, L., S. Kemp, and I. Williams, (2011). Carbon footprinting: towards a universally accepted definition. Carbon Management 2 (1):61-72. doi: $10.4155 / C M T .10 .39$

4. Dewi, S., Khasanah, N., Rahayu, S., Ekadinata A., dan van Noordwijk, M. (2009). Carbon Footprint of Indonesian Palm Oil Production: a Pilot Study. Bogor, Indonesia. World Agroforestry Centre ICRAF, SEA Regional Office.

5. Hairiah K, A. Ekadinata, R.R. Sari, dan S. Rahayu, (2011). Pengukuran Cadangan Karbon: dari tingkat lahan ke bentang lahan. Petunjuk praktis. Edisi kedua. Bogor, World Agroforestry Centre, ICRAF SEA Regional Office, Universitas Brawijaya (UB), Malang, Indonesia

6. Purwanti KD. (2008). Pendugaan Karbon Tersimpan pada Berbagai Tipe Penutupan Lahan dengan Permodelan Spasial Data Pengukuran Lapang dan Inderaja (Studi Kasus Kawasan Puncak dan Cianjur, 
Jawa Barat [skripsi]. Bogor: Fakultas Pertanian. Institut Pertanian Bogor

7. Lasco RD, Pulhin FB, Roshetko JM, dan Banaticla MRN. (2004). LULUCF Climate Change Mitigation Project in the Philippines: a Primer. World Agroforestry Centre. Southeast Asia Regional Research Programme.

8. Lusiana B, Noordwijk MV, dan Rahayu S. (2005). Carbon Stocks in Nunukan, East Kalimantan: a Spatial Monitoring and Modelling Approach. Report from the carbon monitoring team of the Forest Resources Management for Carbon Sequestration (FORMACS) project. Bogor, Indonesia. World Agroforestry Centre - ICRAF, SEA Regional Office. $98 \mathrm{p}$.

9. Agus F., dan I.G.M. Subiksa, (2008). Lahan Gambut: Potensi untuk Pertanian dan Aspek Lingkungan. Balitanah, Balitbang Pertanian. Bogor

10. Rahayu, S., B. Lusiana, dan M. van Noordwijk. (2005). Above ground carbon stock assessment for various land use systems in Nunukan, East Kalimantan. Pp. 21-34. In: Lusiana, B., van Noordwijk, M., and Rahayu, S. (eds.) Carbon Stock Monitoring in Nunukan, East Kalimantan: A Spatial and Modelling Approach. World Agroforestry Centre, SE Asia, Bogor, Indonesia

11. Page, S.E., J.O. Rieley., H.-D.V Boehm, A. Jaya and S.H. Limin. (2002). The Amount Of Carbon Released From Peat And Forest Fire In Indonesia During 1997. Nature, 420:61-65

12. Hatano, R., M. Tomoaki, D. Untung, S.H. Limin, dan A. Syaiful, (2004). Impact of agriculture and wild fire on $\mathrm{CO} 2, \mathrm{CH} 4$ and $\mathrm{N} 2 \mathrm{O}$ emissions from tropical peat soil in Central Kalimantan, Indonesia, Necessity of Establishment of Inventory on Carbon Cycling in Tropical Peatland Ecosystems for Sustainable Agroproduction and Environmental Conservation, Report number 13574012, Field Science Center for Northern Biosphere, Hokkaido University, Sapporo, pp. 11-14.

13. Kyuma, K. (1987). Tropical peat soil ecosystem in Insular Southeast Asia.

14. Wahyunto, Ritung S dan Subagjo H. (2003). Map of Peatland Distribution Area and Carbon Content in Sumatera. Wetland International-Indonesia Program and Wildlife Habitat Canada (WHC).

15. Hooijer, A., Silvius, M., Wösten, H., dan Page, S. 2006. PEAT-CO2, Assessment of $\mathrm{CO} 2$ emissions from drained peatlands in SE Asia, Delft Hydraulics report Q3943.

16. Murayama, S. dan Bakar, Z.A. 1996a. Decomposition of tropical peat soils -1 . Decomposition kinetics of organic matter of peat soils. Japan Agricultural Research Quaterly 30: 145-151.

17. Hadi, A., Haridi, M., Inubushi, K., Purnomo, E., Razie, F. dan Tsuruta, H. (2001). Effects of land -use change on tropical peat soil on the microbial population and emission of greenhouse gases. Microbes and Environments 16: 79-86.

18. Wosten J.H.M., A.B. Ismail and A.L.M van Wijk(1997). Peat subsidence and its practical implications:a case study in Malaysia. Geoderma,78, 25-36.

19. Damen dan Faaij.2007.Greenhouse gas balances of biomass import chains for green electricity production in the Netherlands. Report in the framework of IEA Bio-energy Task 38.

20. Corley, R.H.V. and P.B. Tinker (2003). The Oil Palm -Fourth Edition. Blackwell Science publishers. Nikander, S., 2008. Greenhouse gas and energy intensity of product chain: case transport biofuel. MSc Thesis, Helsinki University of Technology. Helsinki (Finland).

21. ERIA (2007). Investigation on sustainable biomass utilization vision in East Asia: life cycle assessment for biomass derived fuel in Malaysia. ERIA Joint Research Project Series 2007, No. 39

22. IPCC, 2006. Revised 1996 IPCC Guidelines for National Greenhouse Gas Inventories: Reference Manual. Chapter 5 Land-use change \& Forestry.

23. Wijbrans and Van Zutphen. 2005. Environmental impact study for the combustion of palm fatty acid distillate in a power plant. Zwolle (the Netherlands), May 2005.

24. UK-Renewable Fuels Agency (2008). Carbon and sustainability reporting within the renewable transport fuel obligation - Technical guidance part one \& part two. Office of the Renewable Fuels Agency (UK), August 2008. Klaarenbeeksingel, F.W., 2009. Greenhouse Gas Emissions from Palm Oil Production. Literature review and proposals from the RSPO Working Group on Greenhouse Gases. Final Report. Brinkmann consultancy.

25. Wood B.J. and R.H.V. Corley (1993). The energy balance of oil palm cultivation. In: Proceedings 1991 PORIM International Palm oil ConferenceAgriculture. Palm Oil Research Institute Malaysia, Kuala Lumpur, pp 130-143.

26. Rogi, J. E. X. 2002. Penyusunan model simulasi dinamika nitrogen pertanaman kelapa sawit (Elaeis guineensis, Jacq.) di unit Usaha Bekri Propinsi Lampung. Disertasi. Institut Pertanian Bogor, Bogor.

27. Reijnders L., and M.A.J. Huijbregts, 2008. Palm oil and the emission of carbon-based greenhouse gases. Journal of Cleaner Production, 16, 477-482

28. Saifudin, N. and S.A. Fazlili, 2009. Effect of microwave and ultrasonic pretreatments on biogas production from anaerobic digestion of palm oil mill effluent. Am. J. Eng. Applied Sci., 2: 139-146. DOI: 10.3844/ajeassp. 2009.139.146

29. S. Yacob S., M.A. Hassan, Y. Shirai, M. Wakisaka, and S. Subash (2006). Baseline study of methane emission from anaerobic ponds of palm oil mill effluent treatment. Science of the Total Environment 366 (2006), 187 - 196. 